\title{
Essay on the prospects for the use of decorative perennials of the spontaneous flora of the local landscape Feofaniya
}

\author{
(1) Raisa Matiashuk *, (ㄴ) Liubov Gubar, 이 Inna Pirko ** \\ Institute for evolutionary ecology, National Academy of Sciences of Ukraine, Lebedeva str. 37, 03143 Kiev, Ukraine; \\ * raisakiev2015@gmail.com, ** pirkoinna@ukr.net
}

\begin{abstract}
The taxonomic and ecological structure of an artificial set of species of spontaneous flora of the local landscape Feofaniya, distinguished by decorative features, is presented. Decorative perennials, with the exception of aquatic and coastal ones, number 147 species. They are considered taking into account the adaptive characteristics, as a potentially basic component of the regional assortment of ornamental plants for landscaping. In terms of taxonomic composition, the species belong to 100 genera from 38 families. A significant part of perennials is rare in ornamental gardening. Among the studied perennials, the rare fraction includes 13 species with international (four species), state (seven species), or regional (six species) conservation status. According to the results of bioecological analysis, the predominance of mesophytic (76\%), heliophytic (44\%), mesotrophic (82\%), and neutrophilic (65\%) species is shown. When considering the ecological affiliation, the studied species are united into 15 principal ecomorphological groups. The use of plants represented in such groups as the main assortment in the landscaping of the corresponding ecotopes is a prerequisite for the stability and durability of such artificial communities as flower arrangements. The proposed assortment ensures the creation of modern low-cost flower arrangements, as well as the preservation of the biodiversity of the local flora by expanding the cultigen range of these species.
\end{abstract}

Keywords: local landscape Feofaniya, natural resources, rare species, ecomorphs, ecological groups

Authors' contributions: The contribution of all authors to the implementation of geobotanical descriptions, processing of literary materials, and preparation of the main text is equivalent.

Funding: The work was performed at the Institute of Evolutionary Ecology of the National Academy of Sciences of Ukraine within the departmental themes of applied research of scientific institutions "Rational use of nature" in frames of research theme "Development of scientific bases for the creation of elements of natural complexes on the territory of the NPF of Ukraine with recreational loads (6541030), 2021-2023".

Competing Interests: The authors declare that they have no conflicts of interest related to the publication of this manuscript. The authors adhered to ethical standards excluding plagiarism, data falsification, and duplicate publication.

\section{Introduction}

The use of ornamental plants of spontaneous flora in landscaping of settlements is always relevant. However, their presence in regional assortments is rather low, compared to alien species and cultural forms that represent up to $2 / 3$ of the assortments (Griffiths, 1994; Catalog, 1997; Mashkovska, 2015). An even greater imbalance is observed 
in practical gardening, where cultural forms are the main part of the assortment and are represented mainly by cultigens. Such plants have an undeniable aesthetic advantage, but are characterized by a relatively low viability, which necessitates their cultivation on a sufficiently high and costly agricultural background. In turn, the introduction of alien natural species also has its negative consequences - uncontrolled spread sometimes leads to their invasion into anthropogenic transformed and even natural phytocoenoses (Burda et al., 2015; Pergl et al., 2016; Protopopova \& Shevera, 2019; Gubar \& Konyakin, 2020). As a result, the balance of local fauna trophic chains of which are connected with herbaceous plants can be disturbed (Wilde et al,. 2015; Anderson et al., 2021). Therefore, increasing interest of scientists to the investigation of local floras is expedient and justified.

The scientific significance of attracting natural species to culture is also growing taking into account the possibility of preserving highly valuable species within the cultigenic area (Antonyuk et al., 1982; Cherevchenko et al., 1999; Gritsenko, 2012) or by artificial reproduction and further reintroducing into places of its natural distribution.

Modern trends in landscape design, which are based on naturalness, also increase attention to such plants. Their main goal is to create sustainable long-term low-cost plant compositions that actively perform ecological and aesthetic functions, or to design phytocoenoses that are as close as possible to natural. For example, in many countries, some of the usual lawns have been replaced by mauritanian and meadow ones (Kühn, 2006; Bretzel et al., 2016) with using a mixture of seeds, including local species, with bioecological characteristics of the territory of introduction (taking into account phytocoenotic features, plant height, color spectrum, etc.). In recent decades, interest has increased not only regarding the species of spontaneous flora, but also regarding the use of spontaneous vegetation itself, formed in urban ecosystems (Kühn, 2006; Del Tredici, 2010; Pop Boancă et al., 2011). Such plant communities are recommended to be used with their natural structure or with a slightly corrected species composition. Some researchers consider spontaneous vegetation as an important component of urban green space diversity, which is essential for the sustainable development of urban ecosystems (Del Tredici, 2014; Guo et al., 2018). The dominance of alien species in urban landscaping, in their opinion, decreases the functional stability of such ecosystems. Therefore, spontaneous species adapted to environmental conditions should be properly used and conserved.

Thus, attracting ornamental species of local flora for the needs of regional gardening is expedient and relevant. In this regard, the purpose of this study was to isolate from the spontaneous flora of the local landscape Feofaniya the species that have certain decorative value and, basing on the analysis of bioecological characteristics, to assess the prospects of their introduction. Such data can be useful for the needs of landscaping in the park zone of the local landscape Feofaniya, using plants of the regional gene pool (local populations) as an initial material.

\section{Material and methods}

The territory of the local landscape Feofaniya includes the park of the same name. This park is a monument of the landscape gardening art of national importance, which is also an object of the natural reserve fund of Ukraine.

Herbaceous perennials of the spontaneous flora of the local landscape Feofaniya were selected as the material for the study because these plants are the most prospective for the formation of longstanding landscaping objects with low resource investments.

The term 'spontaneous flora' used in this research means a set of aboriginal and adventive species occurring on a particular territory spontaneously, without human intervention (Palmer, 1930). Species names and their taxonomic affiliation are provided following the database World Flora Online (2021).

Ecomorphs of the studied species were delimited relating to four main ecological factors (soil moisture, light, trophic characteristic and acidity of soil) following published data (Didukh, 2000-2010, 2011).

The local landscape Feofaniya, considering physical geography zonality, is located in the Kyiv elevated forest-steppe. Considering 
geobotanical zonality, it is located in the Podolsk-Srednioprydniprovsk sub-province. Here are dominated deciduous forests attributed to the association Galeobdoloni lutei-Carpinetum Shevchyk et al. 1996 emend Onyshchenko et Sidenko 2002, including its three subassociations - caricetosum pilosae, lamietosum maculati, and poetosum. Small areas in the local landscape are occupied by vegetation classes Robinietea Jurko ex Sofron 1980, Salicetea purpureae Moor 1958, and Alnetea glutinosae Br.-Bl. et R. Tx. 1943 (Goncharenko et al., 2013; Dubyna et al., 2019).

\section{Results and discussion}

During compilation of the basic regional assortment of ornamental crops, their evolutionary adaptation, acclimatization, or a high degree of adaptation to natural and climatic conditions, which in general characterizes the species of spontaneous flora, are taking into account. Among them, 147 species were identified belonging to 100 genera from 38 families. All this species differ in degree of decorativeness, have been used for a long time or are offered to use in ornamental gardening. Some of them can be found in botanical collections of many Ukrainian institutions and abroad (Catalog, 1997; Mashkovska, 2015), in various objects of ornamental gardening and landscaping, but, in general, their assortment is insignificant. For example, at the end of 2019, the collection of perennial floral and ornamental plants of Feofania Park was represented by 144 taxa, including 117 cultivars, three forms, five selection samples and only 23 natural species (Radchenko et al., 2019). Moreover, in culture, such species propagate mainly vegetatively, what leads to formation of clones within the cultivated area. Such a depletion of the species gene pool, which in cultural conditions is often represented by a single genotype, results in the vulnerability of used plants and limits their adaptive potential. Such reduced adaptive potential is significantly lower than in the natural populations natural of the species. Therefore, there is a need to attract new genetic material directly from natural populations and to develop new reproduction approaches for such species under cultivation.

We also considered Crocus heuffelianus
Herb and Galanthus plicatus M. Bieb. with other representatives of the spontaneous flora. These two species are represented by experimental artificial plantations outside the park area where they grow in the natural phytocenoses. Similar plantations of other species (Erythronium dens-canis L., Gymnospermium odessanum (DC.) Takht., and Scilla siberica Haw.) were also found in the local landscape. But during long-term observations it was noted that $C$. heuffelianus and G. plicatus have a tendency to intensive reproduction and spontaneous dispersion.

The rest of the decorative species of spontaneous flora belong to the so-called group of 'rare ornamental perennials'. Among them are species occurring in the ornamental gardening rarely. Such plants (e.g., Actaea spicata L., Gagea minima (L.) Ker Gawl., Isopyrum thalictroides L., Pilosella officinarum Vaill., Potentilla incana P. Gaertn., B. Mey. et Scherb., Ranunculus auricomus L., Verbascum nigrum L., and Viola reichenbachiana Jord. ex Boreau) are almost not cultivated even within their natural distribution ranges.

In the local landscape Feofaniya, among the ornamental plants, the most represented are the families Lamiaceae Martinov (17 species), Poaceae Barnhart (13 species), Asteraceae Bercht. et J. Presl (11 species), Fabaceae Lindl. (11 species), Ranunculaceae Juss (11 species), Violaceae Batsch (eight species), and Rosaceae Juss. (seven species). Species of the last two families, as well as of Asparagaceae Juss., Caryophyllaceae Juss., Iridaceae Juss., and Liliaceae Juss. are not numerous, but all of them have a high decorative value. Most of mentioned above families are typical for ornamental gardening in temperate regions (Catalog, 1997; Mashkovska, 2015).

Two adventive ornamental species (Asclepias syriaca L. and Solidago canadensis L.) found in the spontaneous flora of the local landscape Feofaniya were recognized as invasive (Burda et al., 2015; Gubar \& Konyakin, 2020). The source of the invasion is ornamental gardening, so their further use in culture is not desirable.

Among other decorative perennials, 13 species have international, state or regional sozological status (Table 1) and are subject to special protection (Vinichenko, 2006; Didukh, 2009; Andrienko \& Peregrym, 2012; Radchenko et al., 2019; Convention, 2021; IUCN Red 
Table 1. Decorative perennial species in the spontaneous flora of the local landscape Feofaniya subjected to protection.

\begin{tabular}{ll}
\hline Species & Sozological lists (status) \\
\hline Allium ursinum L. & RBU (unvalued) \\
Cephalanthera longifolia (L.) Fritsch & RBU (rare), CITES \\
Corydalis cava (L.) Schweigg. et Koerte. & RRL - Kyiv region \\
Crocus heuffelianus Herb. & RBU (unvalued) \\
Dryopteris austriaca (Jacq.) Woyn. ex Schinz et Thell. & RRL - Kyiv region \\
Galanthus nivalis L. & IUCN (near threatened), RBU (vulnerable), CITES \\
Galanthus plicatus M. Bieb. & ERL (vulnerable), RBU (vulnerable), CITES \\
Gymnocarpium dryopteris (L.) Newman & RRL - Kyiv region \\
Isopyrum thalictroides L. & RRL - Kyiv region \\
Lilium martagon L. & RBU (unvalued) \\
Neottia nidus-avis (L.) Rich. & RBU (unvalued), CITES \\
Primula veris L. & RRL - Kyiv region \\
Scilla bifolia L. & RRL - Kyiv region \\
\hline
\end{tabular}

Note. IUCN - the IUCN Red List of Threatened Species; ERL - European Red List of Globally Threatened Animals and Plants; CITES - Convention on International Trade in Endangered Species of Wild Fauna and Flora; RBU - Red Book of Ukraine; RRL - regional red lists.

List, 2021). Some species (Allium ursinum L., Galanthus nivalis L., G. plicatus M. Bieb., and Scilla bifolia L.) present in the collections of many botanical institutions. They also are quite common in the ornamental gardening. At the same time, such rare species as Cephalanthera longifolia (L.) Fritsch and Neottia nidus-avis (L.) Rich. are not cultivated in Ukraine due to their complex developmental biology (Vakhrameeva et al., 1996; Loya \& Gaponenko, 2009). Despite difficulties, the cultivation of such species in specialized botanical institutions is necessary to not only preserve the genetic material of rare species ex situ, but also for research, scientific, educational and exhibition purposes. This also relates such species as Polygonatum multiflorum (L.) All., Majanthemum bifolium (L.) F.W. Schmidt, Viola mirabilis L., and Paris quadrifolia L., which are not protected, but rapidly disappear under increased anthropogenic load and in a result of disturbance of natural habitats (Goncharenko, 2013). In addition, many species undergoes more and more active and constant uncontrolled collection and destruction. Therefore, cultivation is one of the options for their ex situ conservation at the specialized institutions (e.g., botanical gardens) that can reduce the pressure on their natural populations (Gritsenko, 2012).

For successful introduction, it is necessary to conduct comprehensive investigation of different characteristics, primarily bioecological, which determines the environmental confinement of the species and determine their viability and stability. The ecological analysis of decorative perennials was carried out in relation to four factors (Table 2). Regarding soil moisture, the studied species were subdivided on two groups - mesophilic and xerophilic (Didukh, 2011). Mesophilic group is epresented by $76 \%$ of investigated species (83 species of mesophytes, and 28 species of xeromesophytes). Xerophilic group is represented by $24 \%$ species adapted to arid conditions (five species of mesoxerophytes, and 31 species of xerophytes, including three succulents). The local landscape Feofaniya has mesophilic conditions in relation to soil moisture (Radchenko et al., 2019). This makes possible to consider studied species as suitable for further introduction into local culture.

In relation to light, the species were divided into four groups: sciophytes, heliophytes, sciogeliophytes, and helioscyophytes (Didukh, 2011). The last two groups included plants 
Table 2. Ecological groups of decorative perennials in the spontaneous flora of the local landscape Feofaniya.

\begin{tabular}{|c|c|c|c|c|}
\hline \multirow{3}{*}{$\begin{array}{l}\text { Group } \\
\mathrm{Nr}\end{array}$} & \multicolumn{4}{|c|}{ Environmental factors } \\
\hline & soil moisture & light & soil trophic $\mathrm{p}$ & soil acidity \\
\hline & \multicolumn{4}{|c|}{ Ecological groups } \\
\hline \multirow[t]{5}{*}{ I } & mesophyte & heliosciophyte & mesotrophic & neutrophyte \\
\hline & Agrostis stolon & & Carex spicato & \\
\hline & Ajuga reptans & & Convallaria $n$ & \\
\hline & Brachypodium & (Huds.) P. Beauv. & Pteridium aq & uhn \\
\hline & Carex digitata & & Teucrium cho & \\
\hline \multirow[t]{13}{*}{ II } & mesophyte & sciophyte & mesotrophic & acidophyte \\
\hline & Athyrium filix & Roth. & Gymnocarpir & (L.) Newman \\
\hline & Carex sylvatic & & Lamium gale & \\
\hline & Cephalanthero & L.) Fritsch & Lamium mac & \\
\hline & Chrysospleniu & ium L. & Maianthemur & ) F.W. Schmidt \\
\hline & Corydalis inte & Merat & Neottia nidus & \\
\hline & Cystopteris fro & rnh. & Paris quadrif & \\
\hline & Dryopteris aus & .) Woyn ex Schinz et Thell. & Primula veris & \\
\hline & Dryopteris car & ill.) H.P. Fuchs & Pulmonaria a & \\
\hline & Dryopteris fili & chott. & Pulmonaria o & \\
\hline & Galanthus niv & & Vinca minor & \\
\hline & Galanthus plic & & Viola mirabil & \\
\hline & Galium odorat & & Viola reichen & 1. ex Boreau \\
\hline \multirow[t]{6}{*}{ III } & mesophyte & sciophyte & eutrophic & acidophyte \\
\hline & Actaea spicata & & Ficaria verna & \\
\hline & Allium ursinur & & Isopyrum tha & \\
\hline & Cardamine bu & rantz & Lilium marta & \\
\hline & Cardamine qu & M.Bieb.) Schmalh. & Sanicula eurc & \\
\hline & Corydalis cavo & gg. et Koerte. & & \\
\hline \multirow[t]{3}{*}{ IV } & mesophyte & heliophyte & eutrophic & acidophyte \\
\hline & Allium angulos & & Molinia caer & \\
\hline & Geum rivale $\mathrm{L}$ & & & \\
\hline \multirow[t]{3}{*}{$\mathrm{V}$} & mesophyte & heliophyte & eutrophic & neutrophyte \\
\hline & Alopecurus pro & & Lythrum salic & \\
\hline & Dactylis glome & & Mentha $\times$ pip & \\
\hline \multirow[t]{6}{*}{ VI } & mesophyte & heliophyte & mesotrophic & neutrophyte \\
\hline & Althaea officin & & Phlox panicu & \\
\hline & Deschampsia & .) P. Beauv. & Persicaria an & elarbre. \\
\hline & Eupatorium co & & Potentilla ans & \\
\hline & Euphorbia cyp & & Solidago virg & \\
\hline & Euphorbia sem & kh.) Krylov & Veronica aust & \\
\hline
\end{tabular}


Table 2. Continued.

\begin{tabular}{|c|c|c|c|}
\hline \multirow{3}{*}{$\begin{array}{l}\text { Group } \\
\mathrm{Nr}\end{array}$} & \multicolumn{3}{|c|}{ Environmental factors } \\
\hline & soil moisture & soil trophic properties & soil acidity \\
\hline & \multicolumn{3}{|c|}{ Ecological groups } \\
\hline \multirow[t]{6}{*}{ VI } & mesophyte & mesotrophic & neutrophyte \\
\hline & Geranium pratense L. & Veronica chamaedrys L. & \\
\hline & Fragaria viridis Duchesne & Veronica longifolia L. & \\
\hline & Lysimachia punctata L. & Veronica officinalis L. & \\
\hline & Lysimachia vulgaris L. & Veronica prostrata L. & \\
\hline & Lupinus polyphyllus Lindl. & & \\
\hline \multirow[t]{9}{*}{ VII } & scioheliophyte & mesotrophic & neutrophyte \\
\hline & Anemone ranunculoides L. & Gagea minima (L.) Ker G & \\
\hline & Campanula bononiensis L. & Geranium palustre L. & \\
\hline & Campanula glomerata L. & Melissa officinalis L. & \\
\hline & Campanula rapunculoides L. & Ranunculus acris L. & \\
\hline & Coreopsis auriculata L. & Ranunculus auricomus L & \\
\hline & Corydalis solida (L.) Clairv. & Ranunculus repens L. & \\
\hline & Fragaria vesca L. & Scilla bifolia L. & \\
\hline & Gagea lutea (L.) Ker Gawl. & Thalictrum minus L. & \\
\hline \multirow[t]{3}{*}{ VIII } & mesoxerophyte & mesotrophic & neutrophyte \\
\hline & Artemisia pontica L. & Origanum vulgare L. & \\
\hline & Filipendula vulgaris Moench & Viola hirta L. & \\
\hline \multirow[t]{6}{*}{ IX } & xeromesophyte & mesotrophic & neutrophyte \\
\hline & Asarum europaeum L. & Polygonatum odoratum ( & ill.) Druce \\
\hline & Glechoma hederaceae L. & Stellaria holostea L. & \\
\hline & Lysimachia nummularia L. & Symphytum officinale L. & \\
\hline & Milium effusum L. & Viola suavis M. Bieb. & \\
\hline & Polygonatum multiflorum (L.) All. & & \\
\hline \multirow[t]{6}{*}{$\mathrm{X}$} & xeromesophyte & mesotrophic & neutrophyte \\
\hline & Inula helenium L. & Trifolium medium L. & \\
\hline & Campanula persicifolia L. & Prunella vulgaris L. & \\
\hline & Silene viscaria (L.) Jess. & Phlomoides tuberosa (L.) & oench \\
\hline & Lathyrus vernus (L.) Bernh. & Viola odorata L. & \\
\hline & Lotus corniculatus L. & & \\
\hline \multirow[t]{7}{*}{$\mathrm{XI}$} & xeromesophyte & mesotrophic & neutrophyte \\
\hline & Crocus heuffelianus Herb. & Medicago sativa L. & \\
\hline & Geranium sanguineum L. & Potentilla erecta (L.) Rae & ch. \\
\hline & Iris pseudacorus L. & Securigera varia (L.) Las & \\
\hline & Lathyrus tuberosus L. & Tanacetum vulgare L. & \\
\hline & Lavatera thuringiaca L. & Trifolium alpestre L. & \\
\hline & Medicago falcata $\mathrm{L}$. & & \\
\hline
\end{tabular}


Table 2. Continued.

\begin{tabular}{|c|c|c|c|}
\hline \multirow{3}{*}{$\begin{array}{l}\text { Group } \\
\mathrm{Nr}\end{array}$} & \multicolumn{3}{|c|}{ Environmental factors } \\
\hline & soil moisture & soil trophic properties & soil acidity \\
\hline & \multicolumn{3}{|c|}{ Ecological groups } \\
\hline \multirow[t]{3}{*}{ XII } & scioheliophyte & mesotrophic & neutrophyte \\
\hline & Clematis recta $\mathrm{L}$. & Melica nutans L. & \\
\hline & Lathyrus niger (L.) Bernh. & & \\
\hline \multirow[t]{10}{*}{ XIII } & heliophyte & mesotrophic & neutrophyte \\
\hline & Achillea millefolium L. & Linaria vulgaris Mill. & \\
\hline & Achillea nobilis L. & Potentilla incana P. Gae & ., B. Mey. et Scherb. \\
\hline & Agropyron cristatum (L.) Gaertn. & Ranunculus illyricus L. & \\
\hline & Ajuga genevensis L. & Salvia pratensis L. & \\
\hline & Artemisia austriaca Jacq. & Salvia verticillata $\mathrm{L}$. & \\
\hline & Calamagrostis epigejos (L.) Roth & Saponaria officinalis L. & \\
\hline & Epilobium angustifolium L. & Stachys officinalis (L.) T & \\
\hline & Festuca valesiaca Schleich. ex Gaudin & Verbascum nigrum L. & \\
\hline & Koeleria pyramidata (Lam.) P. Beauv. & & \\
\hline \multirow[t]{5}{*}{ XIV } & heliophyte & oligotrophic & neutrophyte \\
\hline & Eryngium planum L. & Onobrychis viciifolia Sc & \\
\hline & Euphorbia seguieriana Neck. & Pilosella officinarum Vai & \\
\hline & Helichrysum arenarium (L.) Moench & Thymus pulegioides L. sub & pannonicus (All.) Kerguelen \\
\hline & Nepeta cataria L. & Thymus serpyllum L. & \\
\hline \multirow[t]{3}{*}{$\mathrm{XV}$} & heliophyte & oligotrophic & neutrophyte \\
\hline & Sedum maximum (L.) Suter & Sedum acre L. & \\
\hline & Sedum telephium L. & & \\
\hline
\end{tabular}

that are constantly or periodically able to tolerate unusual light intensity. The group of obligate shade-loving plants (sciophytes) in the local landscape Feofaniya consists of 42 species (29\%). The group of shadeloving plants tolerating penumbra conditions (helioscyophytes) consists of eight species (5\%). The group of light-loving plants that, however, are sufficiently adapted to slightly shaded conditions (scioheliophytes) consists of 32 species $(22 \%)$. The group of true lightloving plants (heliophytes) consists of 65 species (44\%). Although forest and ruderal plant communities mainly represent the territory of the Feofaniya, the most of studied species are heliophilic and occur in open areas.

In relation to soil fertility, only 16 species (11\%) grow exclusively on sufficiently organicrich soils and 11 (7\%) are more adapted to poor soils. Most of the studied species (120 species, $82 \%$ ) have a wide adaptation range and can be cultivated in different trophic conditions. Most of mesotrophic plants (96 species, 65\%) are also not demanding on soil acidity, which can vary from slightly acidic to slightly alkaline. The rest of mesotrophic plants (24 species) and many eutrophic plants (12 species) are adapted exactly to acidic soils. Such acidic soils are mainly represented by gray forest and soddy podzolic soils of the Right-Bank Forest-Steppe of Ukraine.

Thus, the studied species represented by a wide range of ecomorphs. Among this diversity, 15 principal ecological groups of decorative perennials were delimited (Table 2). These delimited groups can be applied for creation of landscaping objects and can serve a basic assortment fitting certain environmental 
conditions. However, the number of species in some ecological groups is very low. Completion of these small groups is required and possible in two ways - by infusion of new introduced species with similar ecological preferences, or by merging the certain ecological groups into clusters regarding the determinant ecological factor. For example, in cultural conditions, light often is a key determinant, while other factors usually can be artificially adjusted by moistening, fertilization, acidification, etc. The second most important factor is soil moisture, which can be improved under culture conditions only for species of the mesophilic group. Hence, combination of mesophytes and xerophytes within the same composition is impractical, because in any case one of the groups will appear in unfavorable conditions. Instead of this, sciophilic mesophytes (I-III), heliophilic mesophytes (IV-VI), or heliophilic xerophytes (XIII-XIV) can be combined and thrive (Table 2).

Performed analysis is only the first, initial stage in the study of the using prospects of ornamental plants of spontaneous flora. It does not cover the whole spectrum of environmental factors, the use of which will lead to a strong fragmentation of the defined groups. The investigated factors are the most important and usually are determine adaptation potential for plants.

The provided data can also be used in the selection of assortment for modeling artificial decorative phytocoenoses. At the same time, it is necessary to take into account the natural phytocenotic relationships of the studied species. Also it is crucial to experiment with species that are not phylogenetically close, but united by a set of ecological characteristics into the mentioned groups and their clusters. In particular, for the modeling of nemoral forest phytocoenoses, species of II, III, and IX groups can be used, for nemoral forest edge species of I, VII, VIII, and X groups, for meadow - species of V, VI, and XI groups, for steppe species of XIII and XIV groups.

\section{Conclusions}

It was found that spontaneous flora of the local landscape Feofaniya comprises 147 plant species, characterized by various decorative features. This complex includes species that are floristically rare species or are rare in ornamental gardening, and, in the same time, are promising for implementation in landscaping. The predominance of mesophytic (they comprises $76 \%$ from the total number of investigated species), heliophytic (44\%), mesotrophic (82\%), and neutrophilic (65\%) species has been shown.

According to the complex of environmental factors, decorative species were combined into 15 principal ecomorphological groups, which can be recommended as a basic assortment for the formation of long-term sustainable compositions in appropriate environmental conditions. At the same time, for an optimal compositional solution, further analysis of their phenorhythmical, phenological, habitual, and coloristic spectra is required.

\section{Acknowledgements}

The authors express their gratitude to the researcher of the State Institution "Institute of Evolutionary Ecology of the National Academy of Sciences of Ukraine", Ph.D. Konyakin S.M. for provided recommendations.

\section{References}

Anderson, A. G, Messer, I., \& Langellotto, G. A. (2021). Gardeners' perceptions of Northwestern US. Native plants are influenced by ecological information and garden group affiliation. HortTechnology, 31(4), 458-469, https://doi. org/10.21273/HORTTECH04770-20

Andrienko, T. L., \& Peregrym, M. M. (Eds). (2012). Official lists of regionally rare plants of administrative territories of Ukraine (reference edition). Altpress. (In Ukrainian)

Antonyuk, N. E., Borodina, R. M., Sobko, V. G., \& Skvortsova, L. S. (1982). Rare plants of flora of Ukraine in culture. Naukova Dumka. (In Ukrainian)

Bretzel, F., Vannucchi, F., Romano, D., Malorgio, F., Benvenuti, S., \& Pezzarossa, B. (2016). Wildflowers: from conserving biodiversity to urban greening - a review. Urban Forestry \& Urban Greening, 20, 428-436. https://doi.org/10.1016/j. ufug.2016.10.008

Burda, R. I., Pashkevich, N. A., Boyko, G. V., Fitsaylo, T. V. (2015). Alien species of protected flora of the Forest-Steppe of Ukraine. Naukova Dumka. (In Ukrainian) 
Catalog of flower and ornamental plants of the CIS and Baltic botanical gardens (1997). Central Council of Botanical Gardens of Russia, Botanical Garden of the Academy of Sciences of Belarus. (In Russian)

Cherevchenko, T. M., Moroz, P. A., Kuznetsov, S. I., \& Muzychuk, G. M. (1999). Plant diversity conservation problems ex situ. Plant Introduction, 1, 7-13. (In Ukrainian). https://doi.org/10.5281/ zenodo.3367330

Convention on International Trade in Endangered Species of Wild Fauna and Flora. (2021, August 8). https://www.cites.org

Del Tredici, P. (2010). Spontaneous urban vegetation: reflections of change in a globalized world. Nature \& Culture, 5, 299-315. https://doi. org/10.3167/nc.2010.050305

Del Tredici, P. (2014). The flora of the future: celebrating the botanical diversity of cities. Places Journal, April. https://doi.org/10.22269/140417

Didukh, Y. P. (2011). The ecological scales for the species of Ukrainian flora and their use in synphytoindication. Phytosociocenter. (In Ukrainian)

Didukh, Y. P. (Ed.). (2000-2010). Ecoflora of Ukraine. Vol. 1 (2000), Vol. 2 (2007), Vol. 3 (2004), Vol. 5 (2007), Vol. 6 (2010). Phytosociocenter. (In Ukrainian)

Didukh, Y. P. (Ed.). (2009). Red book of Ukraine. Plants. Globalconsulting. (In Ukrainian)

Dubyna, D. V., Dziuba, T. P., Emelianova, S. M., Bagrikova, N. O., Borysova, O. V., Borsukevych, L. M., Vynokurov, D. S., Gapon, S. V., Gapon, Y. V., Davidov, D. A., Dvoreckiy, T. V., Didukh, Y. P., Zhmud, O. I., Kozyr, M. S., Konischuk, V. V., Kuzemko, A. A., Pashkevych, N. A., Ryff, L. E., Solomakha V. A.,... Yakushenko, D. M. (2019). Prodromus of vegetation of Ukraine. Naukova dumka. (In Ukrainian)

Goncharenko, I. V., Ignatiuk, O. A., \& ShelyagSosonko, Y. R. (2013). Forest vegetation of Feofania tract and its anthropogenic transformation. Ecology and Noospherology, 24(34), 51-63. (In Ukrainian)

Griffiths, M. (1994). Index of garden plants. Timber Press.

Gritsenko, V. (2012). Rare species of plants in steppe culturphytocoenose: the systematic composition, sozological characteristic, the historical aspects of the introduction, the contemporary state. Plant Introduction, 54, 13-21. (In Ukrainian). https://doi.org/10.5281/ zenodo.2541996

Gubar, L. M., \& Konyakin, S. M. (2020). Invasive alien species of plants of the tract "Feofania". Ecological Sciences, 4(31), 167-173. (In Ukrainian)
Guo, P., Yu, F., Ren, Y., Liu, D., Li, J., Ouyang, Z., \& Wang, X. (2018). Response of ruderal species diversity to an urban environment: implications for conservation and management. International Journal of Environmental Research and Public Health, 15(12), 28-32. https://doi.org/10.3390/ ijerph15122832

IUCN Red List of Threatened Species. (2021, August 8). https://www.iucnredlist.org

Kühn, N. (2006). Intentions for the unintentional: spontaneous vegetation as the basis for innovative planting design in urban areas. Journal of Landscape Architecture, 1(2), 46-53. https://doi. org/10.1080/18626033.2006.9723372

Loya, V. V., \& Gaponenko, M. B. (2009). Biological features and distribution of Neottia nidus-avis (L.) Rich. (Orchidaceae Juss.) in the Transcarpathian region. Plant Introduction, 44, 50-55. (In Ukrainian). https://doi.org/10.5281/zenodo.2555381

Mashkovska, S. P. (Ed.). (2015). Catalog of ornamental herbaceous plants of botanical gardens and arboretums of Ukraine. Handbook (electronic edition). (In Ukrainian). http://www.nbg.kiev.ua/ upload/biblio/katalog.pdf

Palmer, E. J. (1930). The spontaneous flora of the Arnold Arboretum. Journal of the Arnold Arboretum, 11(2), 63-119.

Pergl, J., Sádlo, J., Petř́k, P., Danihelka, J., Chrtek, J., Hejda, M., Moravcová, L., Perglová, I., Štajerová, K., \& Pyšek, P. (2016). Dark side of the fence: ornamental plants as a source of wildgrowing flora in the Czech Republic. Preslia, 88(2), 163-184.

Pop Boancă, P. I., Dumitraş, A., Singureanu, V., Clapa, D., \& Mazăre, G. (2011). Ecological and aesthetic role of spontaneous flora in urban sustainable landscapes development. Journal of Plant Development, 18, 169-177.

Protopopova, V. V., \& Shevera, M. V. (2019). Invasive species in the flora of Ukraine. I. Group of highly active species. Geo \& Bio, 17, 116-135. (In Ukrainian)

Radchenko, V. G., Burda, R. I., Pashkevych, N. A., Koniakin, S. N., Krakhmalnyi, O. F., Gaponova, L.P., Matiashuk, R. K., Shupova, T. V., Dubrovsky, Y. V. (2019). Park-monument of landscape art Feofania - a refugium of the biotic diversity of the urban ecosystem of Kyiv. Environmental Sciences, 2(25), 138-146. (In Ukrainian)

Vakhrameeva, M. G., Varlygina, T. I., \& Kulikov, P. V. (1996). Pollenhead long-leaved. Biological Flora of the Moscow Region, 12, 48-60. (In Russian)

Vinichenko, T. S. (2006). Plants of Ukraine under protection of the Bern Convention. Khimjest. (In Ukrainian) 
Wilde, H. D., Kamal, J. K. G., \& Colson, G. (2015). State of the science and challenges of breeding landscape plants with ecological function. Horticulture Research, 2, Article 14069. https://doi. org/10.1038/hortres.2014.69
World Flora Online. (2021, November 10). https:// www.worldfloraonline.org

\section{Окреслення перспектив використання декоративних багаторічників спонтанної флори урочища Феофанія}

Раїса Матяшук *, Любов Губарь, Інна Пірко **

Інститут еволюційної екології НАН України, вул. акад. Лебедєва, 37, Київ, 03143, Україна; * raisakiev2015@gmail.com, ** pirkoinna@ukr.net

Представлено таксономічну та екологічну структура штучної сукупності видів спонтанної флори урочища Феофанія, виділеної за декоративними ознаками. Декоративні багаторічники, за винятком водних та прибережних, нараховують 147 видів. Їх розглянуто, з урахуванням адаптаційних характеристик, як потенційно базову складову регіонального асортименту квітниково-декоративних рослин для озеленення. За таксономічним складом види належать до 100 родів з 38 родин. Значна частка багаторічників $\epsilon$ малопоширеною у декоративному садівництві. Серед досліджуваних багаторічників раритетна фракція нараховує 13 видів, що мають міжнародний (чотири види), державний (сім видів), або регіональний (шість видів) охоронний статус. За результатами біоекологічного аналізупоказано переважання мезофільних (76 \%), геліофільних (44 \%), мезотрофних (82\%) та нейтрофільних (65\%) груп. При розгляді екологічної приналежності досліджувані види об'єднанні у 15 елементарних екоморфологічних груп. Використання представлених у таких групах рослин у якості основного асортименту в озелененні відповідних екотопів $\epsilon$ необхідною умовою стійкості та довговічності штучних угруповань якими $\epsilon$ квітникові композиції. Запропонований асортимент здатний забезпечити створення сучасних маловитратних квіткових композицій i збереження біорізноманіття місцевої флори за рахунок розширення культигенного ареалу цих видів.

Ключові слова: урочище Феофанія, природні ресурси, раритетні види, екоморфи, екологічні групи 